\title{
The influence of Ghana's national culture on latent entrepreneurs: An application of Social Rule System Theory
}

\author{
Martin Owusu Ansah, Richard Chinomona \\ University of the Witwatersrand, Johannesburg, South Africa \\ owusumartin97@yahoo.co.uk
}

\begin{abstract}
The impact of Ghana's national culture on its latent entrepreneurial activities are in frequently studied on - as compare to social, economic and financial influences. The current studyexamined the impact of Ghana's national culture on its latent entrepreneurs amongSmall and Medium Sized Enterprises (SMEs) from the view point of Social Rule System theory. The study employeda simple random sampling technique ineliciting251 respondents from the Business city of Kumasi in Ghana.It employedStructural Equation Modelling statistical technique (SEM) using Amos software version 22 in analysing the data. The results showed that, masculine and high power distance cultures in Ghana have significant positive effects on peoples' intention to become entrepreneurs. High uncertainty avoidance and collective cultures had positive and insignificant effects on latent entrepreneurs. Thestudy presents significant contribution to the existing academic literature on national culture and latent entrepreneurial activities. Italso brings additional step towards a fundamental means of empowering people into SMEs in any developing country. Recommendationsare also providedfor useful suggestionstogovernment and policy makers in Africa towards the improvement of Small and Medium Sized Enterprises.
\end{abstract}

Keywords: Latent Entrepreneur, Culture, Small and Medium Sized Enterprises (SMEs)

\section{Introduction}

The growth of small and medium enterprises has become an importantcircumstance in supportingeconomic development in Africa. Entrepreneurship has become a feasible substitute to formal employment in the subSaharan African region. According to Ryan (2003), ILO (2006),Owusu-Ansah \& Poku (2012) entrepreneurship has become an indispensable means in creating jobs towards the improvement of livelihoods. Acs et al. (2008) posited that, the recognition of entrepreneurship towards the development of nations has been broadly acknowledged from an economic perspective in the various empirical literature.Research continues to encourage the study of entrepreneurshipprimarily in small enterprises (Klotz, Hmieleski, Bradley \& Busenitz, 2014). Sathiabama (2010) observed that, entrepreneurship was becoming an activitytowards the creation ofjobs in countries.Previous studies have investigated the influence of national culture on entrepreneurial activities: Luthans, Stajkovic \& Ibrayeva (2000), Thomas \& Mueller (2000), Mueller \& Thomas (2001), Hayton, George, \& Zahra (2002), Uhlaner \& Thurik (2007), Linán \& Chen (2009), Stephan \& Uhlaner (2010). Cultural distinctions between countries have become significanton nations' level of economic and entrepreneurial growth (GEM, 2004).According to Kreiser et al. (2010) and Fatoki \& Chigonda (2011) cultural attitudes have significant impact on the entrepreneurial activities of a population, a country, a region or an ethnic group. Entrepreneurial activities have strong link with countries' specific cultural tendencies (Lee \& Peterson, 2001). The national culture of one's country impacts its economic outcome - which has a greater effect on national savings rate and income (Guiso et al., 2006).Understanding one's culture is likely to afford responses to meet problems of contemporary business (Naoret al., 2010, Klimas, 2016).OECD (1998) opined that, a cultural environment in which entrepreneurship is highlyvaluedmakes business failure to beseen as a constructive learning experience rather than a basis of embarrassment. Cultural differentiation has been studied on and had proven to have had a significant control on both latent and actual entrepreneurship (Blanchflower \& Oswald, 2000; Audretsch et al., 2007).

Extensive work has been done in the Ghanaian context towards entrepreneurship: Aryeetey \& Ahene (2005) investigated on the varying of policies on business environment for small-medium size enterprises; Boohene et al. (2008) studied on gender, personal values, strategies and small business performance; Abor and Quartey (2010) researched on comparative study on SME development in Ghana and South Africa; Dzisi (2010) studied on women and entrepreneurship; Buame (2010) studied on entrepreneurship education; Owusu-Ansah \& Poku (2012) examined entrepreneurship education as a panacea to graduate unemployment; Ahomka (2014) studied on entrepreneurship and culture; Esson (2015) analysed on the escape to victory, 
youth development, youth entrepreneurship and the migration of Ghanaian footballers whileFalco \& Haywood (2016) examined entrepreneurship versus joblessness - explaining the rise in self-employment.

Conversely, an examination of the extantliterature on entrepreneurial activities in Ghana seemed to show that, the concentration was normally on actual entrepreneurswith limited studies on latent entrepreneurship. According to researchers like: Souitaris et al. (2007) and Van de Zwan et al.(2009), studies on latent entrepreneurship was in early stage which have not been extensively research on in the empirical literature. Again, there was limited relationship with most of the studies with the national culture which according to Hofstede (1980: 9) defined culture as "the collective programming of the mind that distinguishes the members of one group or category of people from the other groups."It then explains that, one's culture serves as a basis for business idea after which education, training as well as motivation from external sources could help improve those business idea. Owusu-Ansah \& Poku (2012) observed a paucity of data onentrepreneurship development in Ghana. Stevenson and Lundström (2001) revealed how entrepreneurial culture was one of the limited strategic areas of entrepreneurial growth.Brooks (2008) also posited that, there wasinadequate number of studies on cultural environments within the context of SMEs in general.The current study seeks to cram the void in the extant literature by examiningthe influence of national culture on latent entrepreneurs' willingness to start small and medium enterprises in developing countries - with specific reference to Ghana.This study consists of sections which includes: literature review; research methodology; data collection procedure; construct operationalisation and measurement; data analysis and discussions; implications of the findings; conclusions; limitations of the study as well as suggestions for future research.

\section{Literature Review}

Literature was reviewed on the social rule system theory as well as each of the variables in the conceptual model.

Social Rule System theory: Social rule system theory (SRST) is a theory with strong root in sociology. Burns \& Deitz (1992) observed that, human social behaviouris well thought-out and synchronized by socially created and replicated systems of regulations in societies. Such rules are grounded on norms, taboos, codes of conduct as well as community customs - which havereal subsistence in social institutions such as family, community and business enterprises (Flam \& Carson, 2008). According to Burns \& Flam (1987), social rules in a system powerfullymanipulatebehaviour and relationsamongmembers within a particular environment or institution. In order to guide and regulateinterface, social rules provide behavior with a decipherable, distinctive patterns and make such patterns comprehensible and momentousfor those who share in the rulingknowledge (Flam \& Carson, 2008). According to Yau, Lee, Chow, Sin \& Tse (2000), systems in societies help reduce uncertainty while increasing predictability and vice versa. Mutual ruleshave essential underpinning for well-informedpeople to derive, create and contrast situational prospects (Wang, Siu \& Barnes, 2008). In grounding the social rule system theory to the current study, it is said that,peoples' ideas and behaviour are normally influenced by the cultural environment they find themselves. People who find themselves in an environment where entrepreneurial activities are part of that society are likely to end up as future entrepreneurs and vice versa.

Small and Medium Enterprises in Ghana: The definition of small and medium enterprise in Ghana has been defined differently by many authors and researchers. Currently, the most widely criterion used - is the number of employees to determine whether a business is small or medium. According to Osei, Baah-Nuakoh \& Sowa (1993), there are variations even in the required number. The Ghana Statistical Service (GSS) classified firms with 10 employees or less as small scale enterprise whilst employees greater than 10 were seen as medium and large-sized enterprises. Conversely, the National Board for Small Scale Industries (NBSSI) in Ghana associated both fixed asset and employees' numbers as part of their criteria. NBSSI defined a Small Scale Enterprise as one whoseemployees were less than 9, with plant and machinery not beyond one thousand Ghana cedis (US\$ 667, subject to the 2011 exchange rate). SMEs in Ghana are speckled transverselyin city centers and rural areas (Boohene, Sheridan \& Kotey, 2008), where many are owned and controlled by Ghanaians with few by foreigners (Quartey, 2003).In the current study,small and medium sized 
enterprisesare classified asshops and business entities that are found in many market centres across the various regions in Ghana.

Latent and Actual Entrepreneurs: Entrepreneurs could be actual or latent. According to a research that was conducted by Pihie (2009), entrepreneurship is classified into actual entrepreneurship, which talks aboutpersons that have alreadyestablishedtheir business and are in operation while the latent entrepreneurship is about people that intend or are willing to start their own business. Vesalainen \& Pihkala (2000) defined latent entrepreneurs as people with alert state of mind that direct attention toward a definitegoal to accomplishit. Latent entrepreneurs are craving to be self-employed in the future and have the prospect to realise self-employment. The first category of entrepreneurship which was the actual entrepreneurship - talks about people that have already established their enterprises or industries.The focal point of the study is on latent entrepreneurs or people who are willing to start their own businesses in the country.

National culture: According to López-Duartea, González-Loureirob, Vidal-Suáreza \& González-Díaza (2016) an increasing body of the existing literature has revealed that, national culture has a greater effect on decision and strategy. National culture is determined by an idea that, each country has people with common history and understanding which are considered a country of consistent culture (Bhaskaran \& Gligorovska, 2009). According toRobock \& Simmonds (1989), national culture explains a set of social models and reactions that tend to clause a population's behavior. Chui, Kwok and Zhou (2016) also observed that, national culture forms part of institutions such as - customs, norms, traditions as well as religion.Culture is the set of system and behavior blueprint that a group of people learns but does not inherit at birth.Hofstede (1980) distinguished between organizational culture and national culture. He assumed that "distinctive" value is specific to national culture while, the organizational culture is identified by "mutual" value within the organization. In the current study, national culture will be termed as norms and values that characterise a group of people living in a particular society or country.

Masculinity Vs Femininity: Masculinityexplains how social gender roles are undoubtedlyseparated.In masculine cultures, male are supposed to be assertive, tough and focused on material success whereas women are supposed to be more modest, tender and are concerned with the quality of life. Femininity dwells on societies in which social gender roles tend to overlap (Hofstede, 1980).In the current study, the definition of Butler (1990) was used. He posited that, countries with high masculine cultures tend to stress on success and status while men dominate in such societies as in the case of the Ghanaian business and trading cultures (Ansah, 2015).

High and Low Power Distance: The degree at which the less influential members of an organisation within a country imagine and acknowledge that power is distributedunevenly (Hofstede, 1991).Power is unstable and it tends to change where people are - for instance a man is expected to be a superior at work place and also a father in a family unit (Hofstede, 2001). High power distance culture show signs ofthe following characteristics: subordinates are always liable when things gowrong; superiors overtlyshow their ranks; the relationship between employers and employees is not moderately close while common divisions are accepted. On the other hand, a low power distance culture is where responsibility is often shared by managers and employees. Subordinates are sometimes assigned important tasks and are treated with respect and trust by their superiors. This study postulates Ghana's culture as one with a very high power distance as revealed by Ansah (2015) on Hofstede cultural dimension.

High and Low Uncertainty Avoidance: It explains the extent at which members feel endangered by doubtful situations. (Hofstede, 1991:113). In a culture that has high uncertainty avoidance,individuals try to stay away from improbability and doubt, seek for conformity and believe in unconditional truths - such people are seen to be of a higher level of nervousness and anxietyin such a society.Written set of laws, formal procedureand ceremonytend to add structure to life. Conversely, a low uncertainty avoidance culture makesit easier to acknowledge the uncertainty and take risks in life and they are less apprehensive and more relaxed(Hofstede, 2001).The current study positions Ghana's culture as one with high uncertainty avoidance where people are afraid to venture into enterprise, they are not familiar with (Ansah, 2015). 
Individualism Vs Collectivism: Individualismgives explanations to societies in which the bond between individuals are loose: each individual is liable to look after himself or herself as well as his or her immediate family. Collectivismrefers to the social order in which individuals from birth onwards are included into an interconnected groups (Hofstede, 1991:51).The cultural distinctiveness of collectivism captures the importance people to the wellbeing of a larger group as opposed to individual welfare (Wagner \& Moch, 1986).The study puts Ghana's society as a society that is highly collectivists - where group initiatives are highly cherished than individual initiatives (Ansah, 2015).

Conceptual Model and Hypothesis Development: Figure 1Shows the conceptual model illustrating five variables. Masculinity, Power Distance, Uncertainty Avoidance, Collectivism are the independent variables while Latent Entrepreneurs is the dependent variable.

Figure 1: The study's conceptual model

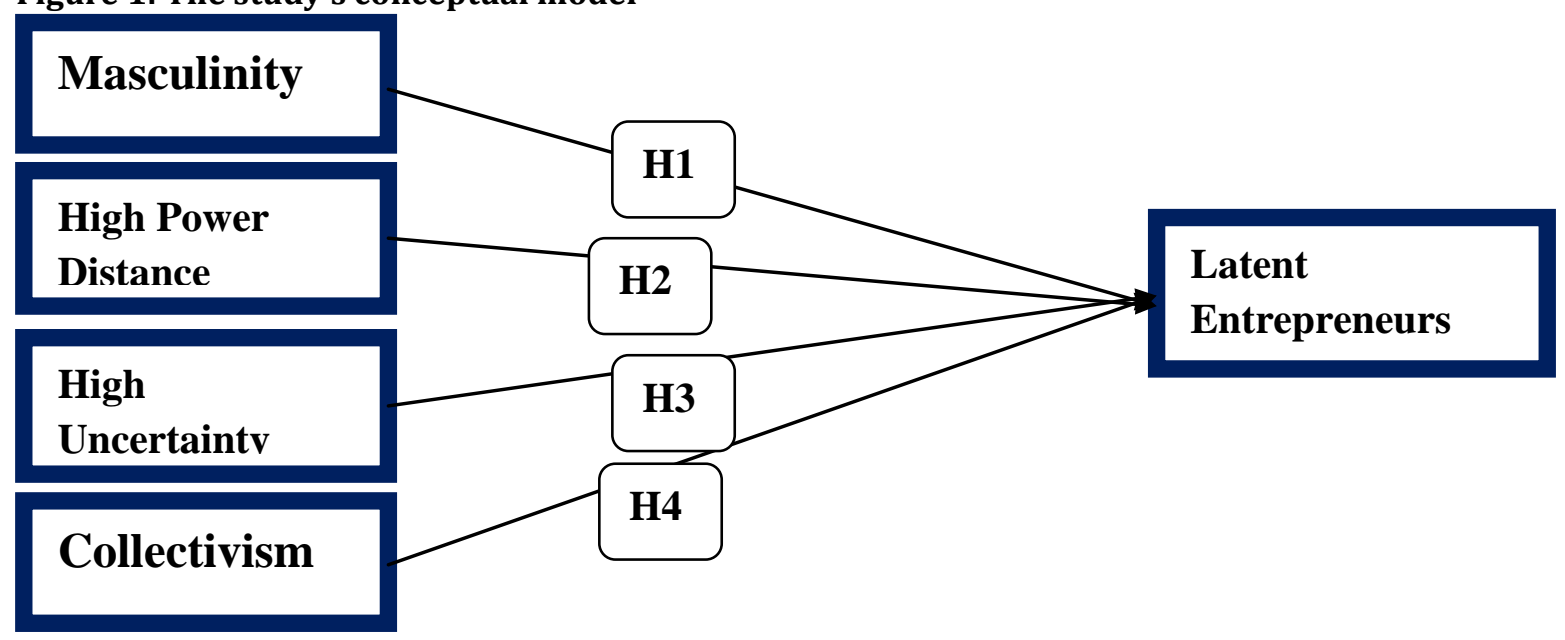

Hypothesis Development: The relationships between the research constructs are discussed in the succeeding pages:

Masculinity and Latent Entrepreneur: Previousstudies have revealed that, entrepreneurship is associated with high levels of individualism (McGrath, MacMillan \& Scheinberg, 1992; Busenitz\& Lau, 1996). According to Roxana (2012), countries with high level of masculinity culture index are likely to take more risk. Dzisi (2014) also posited in her study that, the existence of socio-cultural constraints have effectson thecontribution rate of young women into entrepreneurship. It then suggests that, Ghana's culture is that of masculinity. Chigunta (2002) observed from the developing countries that,involvement of youths into entrepreneurship favours young men who were more likely to be self-employed than young women. It is thus hypothesised in this study that:

H1: A masculine cultural environment has a significant positive effect on peoples'intention to become entrepreneurs.

Power distance and Latent Entrepreneur: Rousseau \& Venter (2002); Neighbors, Lostutter, Cronce \& Larimer, (2007)all observed that, a review ofthe existing of literature seemed to identify that, risk taking behaviour is part of the developmental make-up of the human race. A high Power distance index means that elites in different countries clutchreasonablyto authoritarian views and that influence is based on institutions rather than on secular influence. Highly stratified cultures value traditional values more than autonomy (Roxana, 2012). In high power distance cultures, individuals are expected to be entrepreneurs while in low power distance cultures, people are less likely to be entrepreneurs (Hofstede, 1980). Consequently, depicting from the above deliberations, it can be hypothesised that:

H2: High power distance has a significant positive effect on peoples' intention tobecome entrepreneurs.

Uncertainty Avoidance and Latent Entrepreneur: A multiplicity of studies has led to the conclusion that, cultural values control entrepreneurial behavior. According to Hofstede (1980), national culture replicates 
the fundamental scheme of ideals, philosophy and inclination of a nation. It explains that, the national culture of one's country has a greater influence on his or her make-up.Individuals with low altitude of uncertainty avoidance are likely to be entrepreneurs while persons with high altitude of uncertainty avoidance are less probable to be entrepreneurs (Hofstede, 1980).Researchers like: Shane (1993) andTaylor \& Wilson (2012) also posited that, low level of uncertainty avoidance is associated with entrepreneurship. Corporate risktaking is higher in societies with low uncertainty avoidance than countries with high uncertainty avoidance (Roxana, 2012). The supposition is verified by the modeling work of Giordani \& Zamparelli (2011), who posited that, the lower the ambiguity aversion, the higher the Research \& Development efforts and vice versa. Correspondingly, it is expected that, high uncertainty avoidancecultures are less likely tobe latententrepreneurs. Itis therefore posited that:

H3: High uncertainty avoidance has a negative influence on peoples' intention to become entrepreneurs.

Collectivism andLatent Entrepreneur: According to Licht et al. (2005) individualistic cultures lay emphasis onself-centredness, contest, freedom and entrenched individual liberty and commitment. It is predicted that, individualism is correlated with overconfidence and hopefulness, which tend to have a momentous positive consequence on risk-taking and vice versa (Roxana, 2012). Individualistic persons are more probable to be entrepreneurs while collectivist persons are less likely to be entrepreneurs (Hofstede,1980). Breuer et al. (2011) posited that, individualism is relatedtosuperiority and over optimism and both have constructive effects on individual risk-taking activity while collectivist culture do not promote risk-taking. It is hypothesised that:

H4: Collectivist cultural environment has a negativeeffect on peoples' intention to become entrepreneurs.

\section{Methodology}

The procedures that were used in collecting the data to its eventual analysis of the data are discussed in the succeedingpages:

Sample and data collection: The population for the study was peopleor inhabitants from the business city of Kumasi. The study area (Kumasi) is a cosmopolitan city in Ghana characterised with its trading activities. It is also the capital of Ashanti Region which currently has the largest population in Ghana exceeding the Greater Accra Region (Ghana Statistical Service, PHC 2010). Five undergraduate students from the Kwame Nkrumah University of Science and Technology were recruited and trained as research assistants to give out and collect the questionnaires. Of the total of 300 questionnaires distributed, 251usable questionnaires were reclaimed for the final data analysis, indicating a response rate of $84 \%$.

Measurement Instrument and Questionnaire Design: Research scales were restructured on the basis of precedingresearch work. The national culture wasused as the independent variable in the current study which was adopted from Hofstede (1980) culture dimensions. Proper fine-tuning was made to fit the current research context and purpose. "Masculinity" measure used four-item scale measure,"Power distance" used a four-item scale measure , "Uncertainty avoidance" used a five - item scale measure , Collectivism" used a five item scale measure which were all adapted from Christie et al.(2003) while "Latent entrepreneurs" was measured on a seven-item scale measure which was adapted from ILO(2006), Seed Working paper No.76. All the constructs were measured on afive-point Likert scale- which wasranked from: $1=$ strongly disagree to $5=$ strongly agree to articulate the degree ofagreement and disagreement.

Data Analysis: The analysis of the study's data began with the explanation of the demographic variables before the hypothesised relationship of the variables were discussed.

Respondents' profile: Table 1 explains the depiction of the respondents' characteristics. The participants were predominantly females with $54.2 \%$. A greater majority of the participants were between the ages of 30 39 years constituting $46.2 \%$; $57.8 \%$ of the respondents were married while as many as $23.9 \%$ had masters degrees as their highest educational qualification. 
Table 1: Demographic Characteristic of the Respondents

\begin{tabular}{lll}
\hline Gender & Frequency & Percentage \\
\hline Male & 115 & $45.8 \%$ \\
Female & 136 & $54.2 \%$ \\
Age & $\mathbf{2 5 1}$ & $\mathbf{1 0 0 \%}$ \\
Below 18 years & & \\
18 - 29 years & 10 & $4.0 \%$ \\
30 - 39 years & 50 & $19.9 \%$ \\
40 - 49 years & 116 & $46.2 \%$ \\
50 plus & 55 & $21.9 \%$ \\
& 20 & $8.0 \%$ \\
Marital Status & $\mathbf{2 5 1}$ & $\mathbf{1 0 0 \%}$ \\
Single & & \\
Married & 65 & $25.9 \%$ \\
Divorced & 145 & $57.8 \%$ \\
& 41 & $16.3 \%$ \\
Educational Background & $\mathbf{2 5 1}$ & $\mathbf{1 0 0 \%}$ \\
MSLC /JHS & 35 & $13.9 \%$ \\
SSSCE / WASSCE & 45 & $17.9 \%$ \\
O /A - Level & 41 & $16.3 \%$ \\
Undergraduate & 50 & $19.9 \%$ \\
Masters ( Postgraduate ) & 60 & $23.9 \%$ \\
\end{tabular}

Source: Author's compilation (2016)

Table 2: Accuracy Analysis Statistics

\begin{tabular}{|c|c|c|c|c|c|c|c|c|}
\hline & & & & Cronb & Alpha & & & \\
\hline & & $\begin{array}{l}\text { Descri } \\
\text { Statist }\end{array}$ & & & & & Average & \\
\hline Research Con & tructs & Mean & SD & $\begin{array}{l}\text { Item } \\
\text { Total }\end{array}$ & Value & CR & $\begin{array}{l}\text { Variance } \\
\text { Extracted }\end{array}$ & MFL \\
\hline & MA1 & & & 0.682 & & & & 0.880 \\
\hline & MA2 & & & 0.689 & & & & 0.915 \\
\hline Masculinity & MA3 & 5.1 & 1.5 & 0.732 & 0.942 & 0.958 & 0.852 & 0.956 \\
\hline & MA4 & & & 0.726 & & & & 0.939 \\
\hline & PD1 & & & 0.651 & & & & 0.864 \\
\hline Power & PD2 & & & 0.705 & 0.924 & 0.946 & 0.815 & 0.924 \\
\hline Distance & PD3 & 4.6 & 1.4 & 0.698 & & & & 0.925 \\
\hline & PD4 & & & 0.705 & & & & 0.896 \\
\hline & UN1 & & & 0.737 & & & & 0.826 \\
\hline Uncertainty & UN2 & & & 0.649 & & & & 0.793 \\
\hline Avoidance & UN3 & 5.0 & 1.4 & 0.710 & 0.901 & 0.927 & 0.717 & 0.844 \\
\hline & UN4 & & & 0.735 & & & & 0.889 \\
\hline & UN5 & & & 0.775 & & & & 0.878 \\
\hline Collectivism & & & & & & & & \\
\hline & C3 & 5.2 & 1.4 & 0.601 & 0.730 & 0.849 & 0.654 & 0.699 \\
\hline & $\mathrm{C} 4$ & & & 0.647 & & & & 0.830 \\
\hline & C5 & & & 0.759 & & & & 0.885 \\
\hline Latent & LE2 & & & 0.602 & & & & 0.602 \\
\hline Entrepreneur & LE3 & & & 0.611 & & & & 0.787 \\
\hline $\mathrm{s}$ & LE4 & 5.1 & 1.4 & 0.698 & 0.834 & 0.885 & 0.609 & 0.816 \\
\hline & LE5 & & & 0.710 & & & & 0.799 \\
\hline
\end{tabular}




\section{Journal of Economics and Behavioral Studies (ISSN: 2220-6140)}

Vol. 9, No. 1, pp. 113-126, February 2017

\section{LE6}

0.699

0.871

Source: Author's compilation (2016).

Note: MA = Masculinity; $\mathrm{PD}=$ Power distance; UN = Uncertainty avoidance; $\mathrm{C}=$ Collectivism; LE = Latent entrepreneurs.

$\mathrm{CR}$ value $=$ Composite reliability; $\mathrm{MFL}=$ Measurement factor loadings; $\mathrm{SD}=$ Standard Deviation.

The eliminated constructs in Table 2. Were questions that were deleted in the process of assessing the confirmatory factor analysis (CFA)?

Measure validation: A two-step system approach as recommended by Anderson and Gerbing (1988) was employed before testing the study's hypotheses. Confirmatory factor analysis (CFA) was carried out to assess reliability and validity. Cronbach alpha and composite reliability were used in checking the reliability of the study's construct. Convergent and discriminant validity of measures were assessed using factor loadings as well as the AVE values as shown in Table 2

Measurement CFA Model fit:The overall acceptable model fit was indicated in accordance with the following thresholds: chi - square value $\chi 2 /(\mathrm{df})<3$; Goodness-of- Fit Index (GFI) > 0.9; Root Mean Square Error of Approximation (RMSEA) values< 0.08; Incremental Index of Fit (IFI) $>0.9$; Tucker Lewis Index (TLI) $>0.9$ as well as the Comparative Fit Index (CFI) values $>0.9$ for the estimation of the confirmatory factor analysis.The study's recommended statistics for the final overall model assessment showed an acceptable fit of the measurement model to the data and they are presented as : $\chi 2 /(\mathrm{df})=1.48, \mathrm{GFI}=0.913$; $\mathrm{IFI}=0.980$; $\mathrm{TLI}=$ 0.974; CFI $=0.980 ;$ RMSEA $=0.044$ characterised with the respective CFA diagram at figure 2.

Figure 2: The original diagram for Confirmatory factor analysis

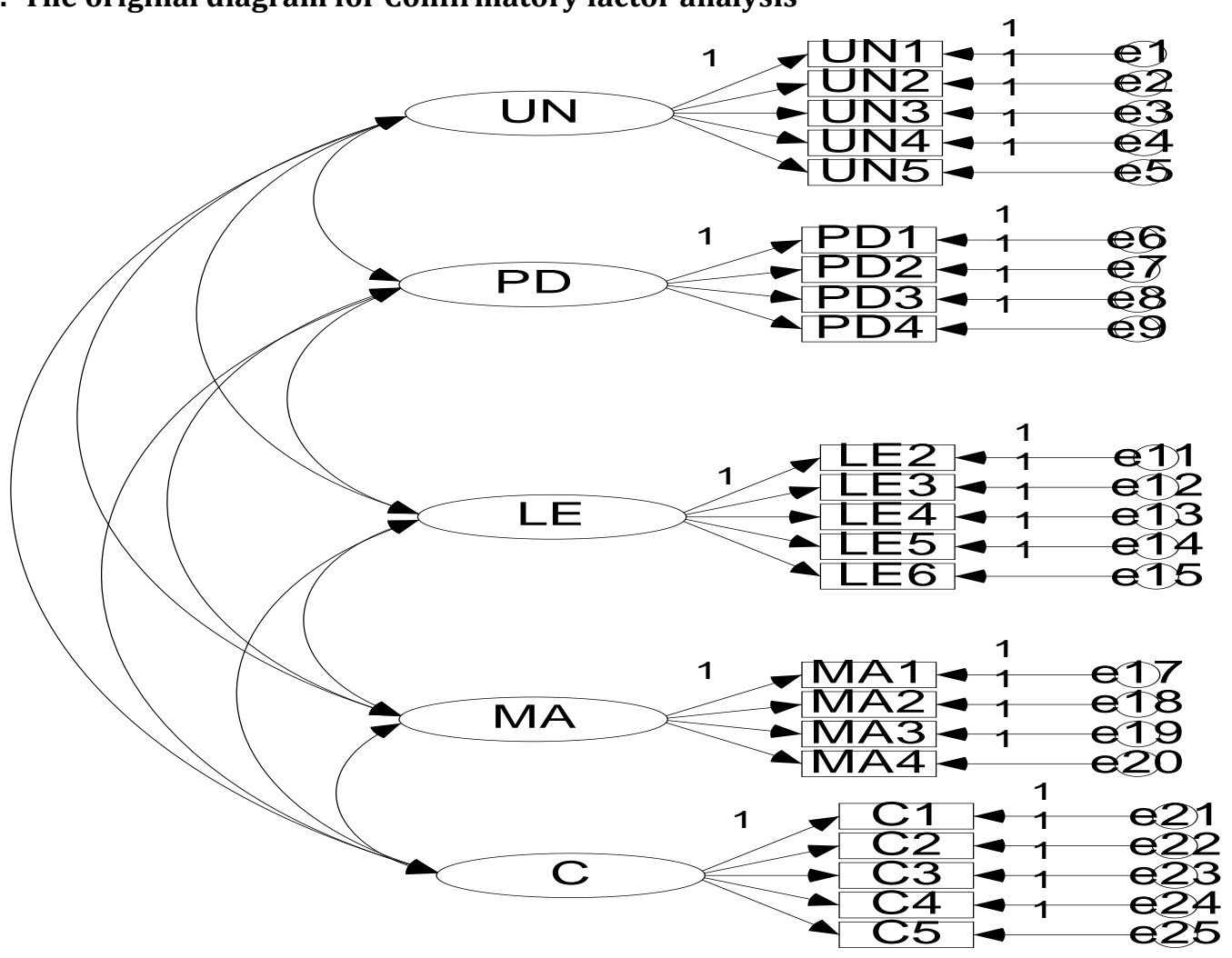

Note: UN = Uncertainty Avoidance; PD = Power Distance; LE = Latent Entrepreneurs; MA= Masculinity = Collectivism.

The estimation of the model measure were all checked to guarantee theirappropriateness before path modelling was employed. Geldhof, Preacher and Zyphur (2014) opined that,composite reliability coefficients 
give a perfectevaluation of reliability than employing alpha coefficients. The present study evaluated validity using: convergent validity and discriminant validity. Convergent validity clarifies how the variables within a single factor are related while discriminant validity assesses the extent to which factors are different and uncorrelated (Gaskins, 2013). Hair et al. (2010:709) posited that, a convergent validity is distinct when a construct's AVE coefficient is 0.5 or higher.The values of the AVE coefficients ranged from 0.609 to 0.852 which were all greater than the least threshold of 0.5. In this study, factor loadings greater than 0.5 as well as AVE values greater than 0.5 was used in assessing the convergent validity. According to Hair et al. (2010) the use of composite reliability coefficients of 0.7 and above indicate a high level of construct reliability. It is seen from the table 2 that, all the constructs used in the current study offered high levels of reliability ranging from 0.849 to 0.958 . According to Du Plessis (2010), a Cronbach's alpha results exceeding 0.6 replicates the least possible level of acceptability. The Cronbach alpha values far exceeded the proposed threshold of 0.6 with values ranging from 0.730 to 0.942 as shown in Table 2 .

Table 3: Inter - Construct Correlation Matrix

\begin{tabular}{llcccc}
\hline Research Constructs & C & LE & MA & PD & UN \\
\hline Collectivism (C) & $\mathbf{1 . 0 0 0}$ & & & & \\
Latent Entrepreneurs (LE) & 0.645 & $\mathbf{1 . 0 0 0}$ & & & \\
Masculinity (MA) & 0.629 & 0.592 & $\mathbf{1 . 0 0 0}$ & & \\
Power Distance (PD) & 0.577 & 0.514 & 0.539 & $\mathbf{1 . 0 0 0}$ & \\
Uncertainty Avoidance (UN) & 0.740 & 0.604 & 0.655 & 0.751 & $\mathbf{1 . 0 0 0}$ \\
\hline
\end{tabular}

According to Fornell \& Larcker (1981) the use of square root of AVE in each latent variable facilitatesthe calculation of discriminant validity, in a situation where thevalue in question is higher than other correlation values between the latent variables.Table 3 shows the least average variance extracted among the latent variable as Latent entrepreneurs with an AVE value of 0.609, which is even the lowest among the variables; hence its square root becomes 0.780 is larger than the correlation values among all the other variable. The resultindicates that, discriminant validity is well acknowledged. Therefore, the results substantiate the existence of discriminant validity of the measurement used in the study.

\section{Results}

Results of structural model analysis: This study used structural equation modeling statistical technique (SEM) to estimatethe causal relationship among the constructs based on the conceptual model in Figure 1. The results are reported in Table 4. The model was acceptable in terms of overall goodness of fit. Acceptable model fit was indicated by $\chi 2$ (df) values < 3; GFI and AGFI values >.90; RMSEA values <0.08; IFI and CFI values >.90. The results of current study indicated that: $\chi 2$ (df) (1.15); GFI (0.945); IFI (0.996), TLI (0.994), CFI (0.996) as well as RMSEA (0.024). It demonstrated how all the thresholds were met in determining the hypothesised relationships (Hair et al., 2010). This suggests that, the model converged well and had acrediblemanifestation of the fundamental empirical data structures collected in the Business city of Kumasi.

Table 4: Results of Structural Equation Model Analysis

\begin{tabular}{lllll}
\hline Path Coefficient & Hypothesis & Factor Loading / P- value & $\begin{array}{l}\text { Supported } \\
\text { Rejected }\end{array}$ \\
\hline $\mathrm{MA} \longrightarrow$ Latent Entrepreneurs & $\mathrm{H} 1$ & $0.358+* * *$ & Supported \\
$\mathrm{PD}$ & Latent Entrepreneurs & $\mathrm{H} 2$ & 0.202 & $+* * *$ \\
$\mathrm{UN} \longrightarrow$ Latent Entrepreneurs & $\mathrm{H} 3$ & $0.183 \quad+$ & Rejected \\
$\mathrm{C}$ & $\mathrm{H} 4$ & $0.158 \quad+$ & Rejected \\
\hline
\end{tabular}

Note: $\mathrm{MA}=$ Masculinity; $\mathrm{PD}=$ Power distance; UN = Uncertainty avoidance; $\mathrm{C}=$ Collectivism; LE = Latent entrepreneurs

Note: Significance level $<0.05$, Significance level $<0.01$; Significance 0.001

Research structural model fits: $\chi \mathbf{2}(\mathrm{df})=1.15 ; \mathrm{GFI}=0.945 ; \mathrm{AGFI}=0.915 ; \mathrm{IFI}=0.996, \mathrm{TLI}=0.994, \mathrm{CFI}=$ 0.996 , and RMSEA $=0.024$.

Testing of Hypothesis: The results in Table 4 provides explanations for all the four hypotheses. The path coefficients for $H 1, H 2, H 3$ and $H 4$ were:0.358; $0.202 ; 0.183$ and 0.158 respectively.Hypothesis (H1) posited a 
positive relationship between masculinity and latent entrepreneurs. The resultssupported the stated hypothesis with a strong and significant value of (0.358).Hypothesis (H2) posited a positive significant relationship between High power distance culture and people intention to become entrepreneurs.Figure 3 and table 4 explain the relationship with a positive values instead of negative. Hypothesis (H3) posited a negative relationship between High uncertainty avoidance and people intention to become entrepreneurs. It then violates the stated hypothesis statement with a positive value of $(0.183)$ while Hypothesis (H4) also posited a negative relationship between a collectivist cultural environment and people intention to become entrepreneurs.The stated hypothesis statement was againrejectedsince it was stated in a negativeform but turned out to be positive with a significant value of (0.158). The values of the various relationships are shown using the beta $(\boldsymbol{\beta})$ values in the modified diagram in the path analysis in Figure 3.

Figure 3: A Modified diagram for path analysis

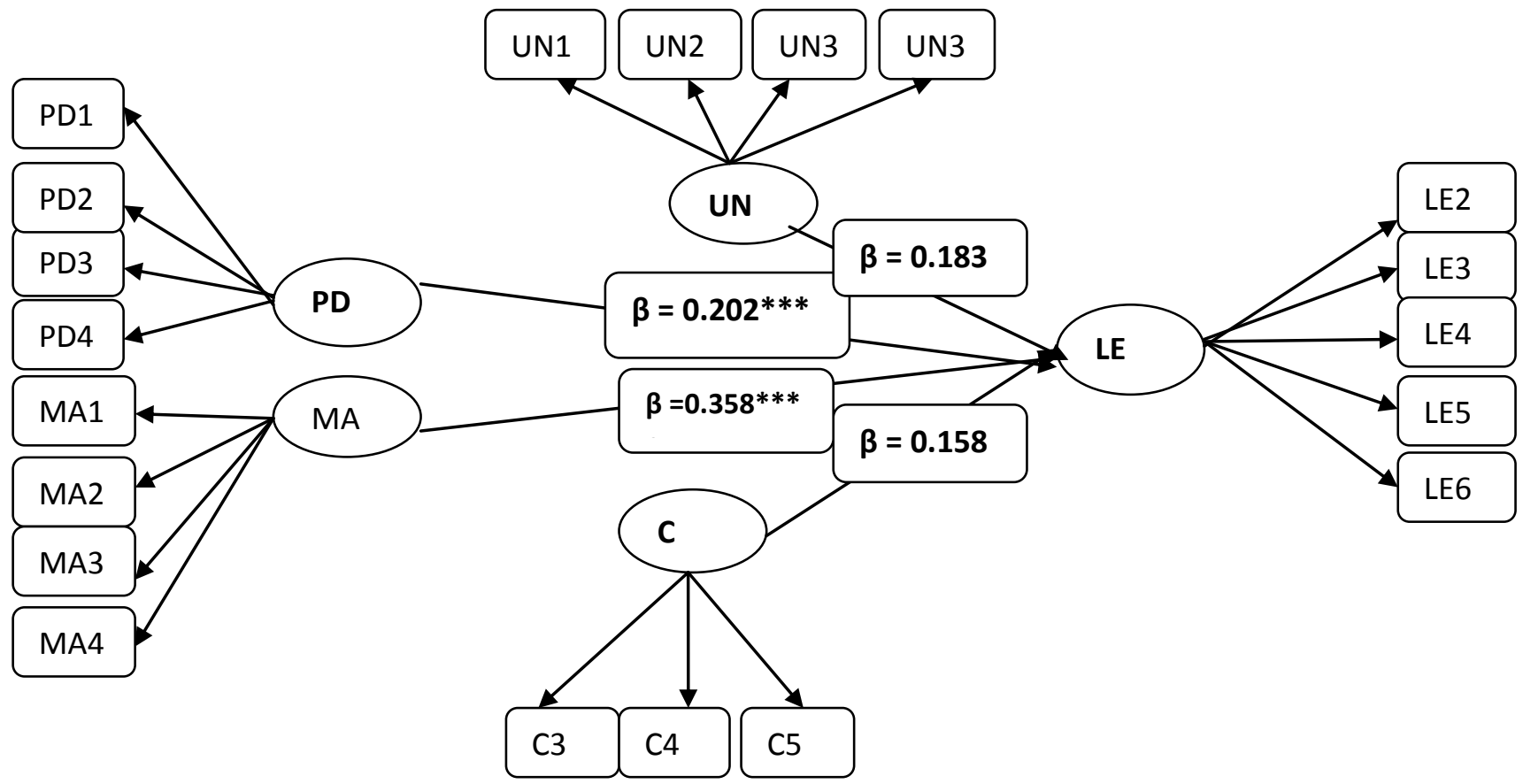

Note: UN = Uncertainty Avoidance; PD = Power Distance; LE = Latent Entrepreneurs; MA= Masculinity = Collectivism.

$\chi 2(\mathrm{df})=1.15 ; \mathrm{GFI}=0.945 ; \mathrm{AGFI}=0.915 ; \mathrm{IFI}=0.996, \mathrm{TLI}=0.994, \mathrm{CFI}=0.996$, and $\mathrm{RMSEA}=0.024$.

Discussion of Results: Hypothesis (H1) posited a significant positive relationship between masculinity and latent entrepreneurs. The results shown in Figure 3 and Table 4. supported the hypothesis with a strong and significant value of (0.358).The results showed that, masculine cultures tend to propel people to become entrepreneurs. The findings are in consistent with Roxana (2012) who posited that countries with high altitude of the masculinity manifestations are liable to take more risk. It explains that, a society that is more masculine with males dominating in their everyday activities are likelyto turn out more entrepreneurs than in a feminine society. It again points to Burns \&Deitz (1992) analysis on the social rule system - where social actions are coordinated by socially created systems of regulations in societies. Hypothesis (H2) also posited a significant positive relationship between High power distance culture and people intention to become entrepreneurs. Figure 3 and Table 4 explained the relationship with a significant value of (0.202); which concluded that, a society with a high power distance culture tend to motivate people to become entrepreneurs. When a society has a strong gap in relationship between the elderly and the young ones, there is a possibility that, the elderly may suggest a business idea which is possible to be adopted by the young especially father and a child as seen in most retail businesses. The study findings are in consonance with Hofstede's (1980) observation towardshigh power distance cultures, where he revealed that,personsin such cultures have a greater probability of becoming entrepreneurs ; less in low power distance and vice versa. 
Hypothesis (H3) posited a negative relationship between High uncertainty avoidance and people intention to become entrepreneurs. It violatedor rejectedthe stated hypothesis statement. Figure 3 and Table 4 explicated the relationship with a positive value of $(0.183)$; which explained that, a society with a high uncertainty avoidance culture affect peoples' intentions to become entrepreneurs but not in a negative way. The findings of the current study are contrary to the findings of Taylor \& Wilson (2012) as well as Roxana (2012) who ascribed that, low levels of uncertainty avoidance is associated with entrepreneurship. The findings are applicable to Burns \&Deitz (1992) observations on the social rule system, where he posited that policies and programs in societies have a greater likelihood to amend the already existing policies in such society. The more people become engage as a result of policies in one's country, the greater the probability of affecting their espoused cultural values. Though Ghana is categorised as a country with high uncertainty avoidance index (Ansah, 2015).The socio - economic factors put in place by previous and current governments in empowering entrepreneurs to revamp the economy has rejected the myth of the cultural tendencies in the academic literature. People are now poised to establish on their own despite all evidence to the contrary in the extant academic literature.

Hypothesis (H4) also posited a negative relationship between a collective cultural environment and people intention to become entrepreneurs. The stated hypothesis statement was again violated with a positive value of (0.158); which clarified that, a society that is collective in nature does not affect its peoples' intentions to become entrepreneurs from the Ghanaian perspective.The findings are again contrary to the results of Hofstede (1980); Breuer et al. (2011) who all posited that, collectivist cultures were more probable not to produce entrepreneurs. According to Burns \& Flam (1987) social rules in a system tend to effectively control the behaviour of members within that environment or institution. A new system or changes in policies directives in a society has a greater influence in the activities of people living in that society (Burns \&Deitz, 1992).The promotion of entrepreneurial activities in supporting groups or associations inestablishing businesses on their own in Ghana might have had a greater influence in seeing collective groups doing more than on individual basis. It is also evident from the study's demographic characteristics that, majority of the respondents had masters degrees as their highest educational qualification - which might compel them in putting their resources together so as to establish on their own rather than to venture into business on individual basis.

\section{Conclusion}

The current study sought to examine the influence of national culture on latent entrepreneurs. Social rule system theory was provided as the theoretical grounding for the framework that was conceptualised for the study. The study postulated four hypotheses, data were collected from people who were not entrepreneurs but were poised to be entrepreneurs in future within the Business city of Kumasi in Ghana. The empirical findings did not support all the stated hypotheses - with some revealed in a varied way.It is therefore concluded that,masculine culture in Ghana has a greater influence on peoples' intent to becomeentrepreneurs. It shows how the systems in societies tend to shape the behaviour of people in that society or country. Programs are mostly structured in favouring men in many sphere of the average Ghanaian life - where men are regarded in many areas than women thereby giving advantage to males over females.Also, high power distance culture and people willingness to start their own businesses was also seen to be significant and positive. The more the gap between managers and employees' become clear - in terms of inequality between business owners and employees; the ideal managers or business owner being autocratic or acted as father as well as differences in privileges and status; the more likely to compel many people who want to be bosses to themselves to set up on their own.

In addition, high uncertainty avoidance culture was also seen to have a positive significant influence on latent entrepreneurs. The result then concluded that, social rule system in a form of policies and programmes in countries has greater effects on the behaviour of people in that country. Entrepreneurial programs by the government are refuting the idea of high uncertainty avoidance cultures negatively affecting latent entrepreneurship. Finally, collectivist culture also had a positive significant relationship with peoples' intention to be entrepreneurs other than a negative one - as stated in the hypothesis. The more the social system is structured in tackling some social - economic problems through education and training, the more people become familiar with new ways of doing things which are likely to violate the conformist way of 
getting things done. The increased number of respondents being literates is more likely to influence the idea of putting capital or resources together in carrying out business activities rather than establishing on individual basis - considering the cost - benefit analysis.

Implication of the study: The current study makes extensive contribution to academic literature, business activitiesand policy towards small and medium size enterprises in Ghana and Africa.First, on the side of the academic, the influence of national culture on latent entrepreneurs -other than actual entrepreneurs in developing countriesin Africa is expected toadd knowledge to the existing ones, since it was observed from the empirical literature that, studies on latent entrepreneurs very were scant.Secondly, contribution to business was made evident in the study as there was a growing evidence in the literature that,countries with high uncertainty avoidance tend to have negative association with entrepreneurs but the current study's findings had given different results - signifying that, the more people in a particular country become more educated, there is that likelihood that, they might begin to reason independently - which then affect their intention to establish on their own. Recent programs on entrepreneurship education among institutions' might one way or the other compel young and educated to set up on their own. Finally,the study also provides a contribution to policy by urging governments in making entrepreneurial activities a compulsory programme for the youth and people in Africa - especially those inschools. There should be an introduction of Entrepreneurship Education Innovation Fund (EEIF) to support the entrepreneurial programmesso as to increase the number of entrepreneurs in Ghana and Africa.The study finally submits that, the small business activities in countries - especially in Africa could contribute to the reduction of unemployment situation in the sub region.

Limitations and future research: The current study makes significant contributions to both academia, business and practice. However, it has its own limitations. The study's data were gathered from only respondents in Kumasi. The results would be more helpful if data from the other part of Ghana are compared. Future studies may be conducted by increasing the sample size to cover the rest of the ten regions in Ghana.

\section{References}

Abor, J. \& Quartey, P. (2010). Issues in SME development in Ghana and South Africa. International Research Journal of Finance and Economics, 39(6), 215-228.

Acs, Z. J., Desai, S. \& Klapper, L. (2008). What does entrepreneurship data really show? Small Business Economics, 31(3), 265-281.

Ahomka, M, Y. (2014) Analysis of Entrepreneurship: How does Culture Influence Risk-Taking in SMEs inthe Sekondi-Takoradi Metropolis, Ghana? American International Journal of Contemporary Research, 4 (2), February 2014

Anderson, J. C. \& Gerbing, D. W. (1988). Structural equation modeling in practice: A review and recommended two-step approach. Psychological bulletin, 103(3), 411.

Ansah, O. M. (2015). Cultural Dimension In Marketing Managers' Decision Making: An Application Of Geert Hofstede Index For Ghana.European Journal of Research and Reflection in Management Sciences,3(2), 2015 ISSN 2056-5992.

Aryeetey, E. \& Ahene, A. A. (2005). Changing regulatory environment for small-medium size enterprises and their performance in Ghana. Centre on regulation and competition working paper series, paper no.103.

Audretsch, D. B., Grilo, I. \& Thurik, A. R. (2007). Explaining entrepreneurship and the role of policy: a framework. The handbook of research on entrepreneurship policy, 1-17.

Bhaskaran, S. \& Gligorovska, E. (2009). Influence of national culture on trans-national alliance relationships. Cross Cultural Management.An International Journal, 16(1), 44-61.

Blanchflower, D. G. \& Oswald, A. (2000). The rising well-being of the young. Youth employment and joblessness in advanced countries (pp. 289-328) University of Chicago Press.

Boohene, R., Sheridan, A. \& Kotey, B. (2008). Gender, personal values, strategies and small business performance: A Ghanaian case study. Equal Opportunities International, 27(3), 237257.

Breuer, W. R., Michael, S. \& Astrid, J. (2011). Risk Aversion vs. Individualism: What Drives Risk Taking in Household Finance? Available at SSRN: http://ssrn.com/abstract=1956777. 
Brooks, B. (2008). The natural selection of organizational and safety culture within a small to medium sized enterprise (SME).Journal of Safety Research, 39, 73-85.

Buame, C. K. (2010). Five Years of Entrepreneurship Education Program at the University of Ghana. Looking Forward to Look Back.75-92.

Burns, T, R. \& Dietz, T. (1992). Cultural Evolution: Social Rule Systems, Selection and Human Agency. International Sociology, 7(3), 259-283. http://dx.doi.org/10.1177/026858092007003001 (Accessed on November, 2015)

Burns, T, R. \& Flam, H. (1987). The Shaping of Social Organization: Social Rule System Theory with Applications. London: Sage Publications.

Busenitz, L. W. \& Lau, C, M. (1996). A cross-cultural cognitive model of new venture creation. Entrepreneurship Theory \& Practice, 20(4), 25-39.

Butler, J. (1990). Gender trouble, feminist theory, and psychoanalytic discourse. Feminism/postmodernism, 327.

Chigunta, F. J. (2002). Youth entrepreneurship: Meeting the key policy challenges (pp. 1-34). Education Development Center.

Christie, P. J., Kwon, I. W., Stoeberl, P. A. \& Baumhart, R. (2003). A cross -cultural comparison of ethics attitudes of Business Managers: India, Korea and United States.www.proquest.umi.com (Retrieved on 12th November 2015)

Chui, A. C. W., Kwok, C. C. Y. \& Zhou, G. S. (2016).National culture and the cost of debt. Journal of Banking \& Finance,69, 1-19

Du Plessis, L. (2010). Customer relationship management and its influence on customer loyalty at Liberty Life in South Africa. University of Johannesburg.

Dzisi, S. (2010). Ghanaian Women and Entrepreneurship. Pent Vars Business Journal, 4(1). Jan - March, 2010 (Published by Pentecost University College).

Dzisi, S. (2014). Youth Entrepreneurship: Investigating Obstacles to Youth Enterprise Creation and Development. International Journal of Economics, Commerce and Management,2(7).

Esson, J. (2015). Escape to victory: Development, youth entrepreneurship and the migration of Ghanaian footballers. Geoforum, 64, 47-55.

Falco, P. \& Haywood, L. (2016). Entrepreneurship versus joblessness: Explaining the rise in self-employment. Journal of Development Economics, 118, 245-265.

Fatoki, O. \& Chindoga, L. (2011). An Investigation into the Obstacles to Youth Entrepreneurship in South Africa. International Business Research,4(2).

Flam, H. \& Carson, M. (2008). Rule system Theory: Applications and Explorations. Berlin/New York: Peter Lang.

Fornell, C. \&Larcker, D. F. (1981). Evaluating structural equation models with unobservable variables and measurement error. Journal of Marketing Research, 18(1), 39-50.

Gaskins, J. (2013). Confirmatory factor analysis. [Internet: http://statwiki.kolobkreations.com/wiki/ Confirmatory_Factor_Analysis. Downloaded 2015-09-20.

Geldhof, G., Preacher, K. \&Zyphur, M. (2014). Reliability estimation in a multilevel confirmatory factor analysis framework. Psychological Methods, 19(1), 72-91.

Ghana statistical service. (2010). Children, Adolescents, Young People in Ghana. 2010. Population and Housing Census Report. Accra

Giordani, P. \&Zamparelli, L. (2011). On robust asymmetric equilibria in asymmetric R\&D-driven growth economies.Decisions in Economics and Finance, 34(1), 67-84.

Global Entrepreneurship Monitor (GEM). (2004). Executive report, Babson College Babson Park, MA, USA/ LBS, London, UK.

Guiso, L., Paola, S.\& Luigi, K. (2006). Does Culture Affect Economic Outcomes? Journal of Economic PerspectivesAEA, 20(2), 23-48.

Hair, J., Black, W., Babin, B.\& Anderson, R. (2010). Multivariate data analysis: a global perspective. 7th ed. Upper Saddle River, NJ: Pearson.

Hayton, J. C., George, G. \& Zahra, S. A. (2002). National culture and entrepreneurship: A review of behavioral research. Entrepreneurship: Theory \& Practice, 26(4), 33-52.

Hofstede, G. (1980). Culture's Consequences: International Differences in Work-Related Values. Beverly Hills CA: Sage Publications.

Hofstede, G. (1991).Cultures and Organizations: Software of the Mind, McGraw-Hill, Berkshire, England. 
ILO. (2006). Stimulating Youth Entrepreneurship: Barriers and Incentives to Enterprise Start Ups by young People. SEED Working Paper No. 76.

Hofstede, G. (2001). Culture's recent consequences: Using dimension scores in theory and research. International Journal of cross cultural management, 1(1), 11-17.

Klimas, P. (2016). Organizational culture and coopetition: An exploratory study of the features, models and role in the Polish Aviation Industry.Industrial Marketing Management, 53, 91-102.

Klotz, A. C., Hmieleski, K. M., Bradley, B. H. \&Busenitz, L. W. (2014). New Venture Teams: A Review of the Literature and Roadmap for Future Research. Journal of Management, 40(1), 226-255.

Kreiser, P. M., Marino, L. D., Dickson, P.\& Weaver, K. M. (2010). Cultural influences on entrepreneurial orientation: The impact of national culture on risk taking and proactiveness in SMEs. Entrepreneurship Theory and Practice, 34(5), 959-983.

Lee, S. M. \& Peterson, S. J. (2001). Culture, entrepreneurial orientation, and global competitiveness. Journal of world business, 35(4), 401-416.

Licht, A. N., Chanan, G. \& Shalom, H. S. (2005). Culture, Law, and Corporate Governance.International Review of Law and Economics, 25, 229-55.

Linán, F. \& Chen, Y. W. (2009). Development and cross cultural application of a specific instrument to measure entrepreneurial intentions. Entrepreneurship: Theory and Practice, 33(3), 593-617.

López-Duartea, C., González-Loureirob, M., Vidal-Suáreza, M. \& González-Díaza, B. (2016). International strategic alliances and national culture: Mapping the Field and developing a research agenda. Journal of World Business, 51, 511-524.

Lundstrom, A. \& Stevenson, L. (2001). Entrepreneurship Policy for the Future. Swedish Foundation for Small Business Research. Stockholm.

Luthans, F., Stajkovic, A. D. \&Ibrayeva, E. (2000). Environmental and psychological challenges facing entrepreneurial development in transitional economies. Journal of World Business, 35(1), 95-110.

McGrath, R. G., MacMillan, I. C. \& Scheinberg, S. (1992). Elitists, risk-takers, and rugged individualists an exploratory analysis of cultural-differences between entrepreneurs and non-entrepreneurs. Journal of Business Venturing, 7(2), 115-135.

Naor, M., Linderman, K. \& Schroeder, R. (2010). The globalization of operations in Eastern and Western countries: Unpacking the relationship between national and organizational culture and its impact on manufacturing performance. Journal of operations management, 28(3), 194-205.

Mueller, S. L. \& Thomas, A. S. (2001). Culture and entrepreneurial potential: A nine country study of locus and control and innovativeness. Journal of Business Venturing, 16(1), 51-75.

Neighbors, C., Lostutter, T. W., Cronce, J. W. \&Larimer, M. E. (2007). Exploring College Student Gambling Motivation. Journal of Gambling Studies, 18(4), 361-370.

OECD. (1998). Fostering Entrepreneurship. Paris.

Osei, B., Baah-Nuakoh, A., Tutu, K. A.\& Sowa, N. K. (1993). Impact of structural adjustment on small-scale enterprises in Ghana. Small Enterprises and Changing Policies: Structural Adjustment, Financial Policy and Assistance Programmes in Africa, IT Publications, London.

Owusu-Ansah \& Poku. (2012). Entrepreneurship Education. A Panacea to Graduate Unemployment in Ghana. International Journal of Humanities and Social Science,2(15)

Pihie, Z. A. L. \& Akmaliah, Z. (2009). Entrepreneurship as a career choice: An analysis of entrepreneurial selfefficacy and intention of university students. European Journal of Social Sciences, 9(2), 338-349.

Quartey, P. (2003). Financing small and medium enterprises (SMEs) in Ghana. Journal of African Business, $4(1), 37-55$.

Robock, S. H. \& Simmonds, K. (1989).International Business and Multinational Enterprises, Irwin, Homewood, Illinois.

Rousseau, G. G. \& Venter, D. L. J. (2002). Measuring consumer attitudes towards gambling. SA Journal of Industrial Psychology, 28(2), 87-92.

Roxana, M. (2012). Effects of Culture on Firm Risk-Taking: A Cross-Country and Cross-Industry Analysis.IMF Working Paper, IMF Working Paper

Ryan, C. (2003). Programme Priorities 2003-2006 Youth Enterprise Development, Strategic Paper by the Common Wealth Secretariat, London. Common Wealth Secretariat.

Sathiabama, K. (2010). Rural women empowerment and entrepreneurship development [Online]. Available: http://www.microfinancegateway.org/ga (Retrieved November, 2015). 
Shane, S. (1993). Cultural influences on national rates of innovation. Journal of Business Venturing, 8(1), 5973.

Souitaris, V.,Zerbinati, S. \& Al-Laham, A. (2007). Do entrepreneurship programmes raise entrepreneurial intention of science and engineering students. The effect of learning, inspiration and resources. Journal of Business Venturing, 22(4), 566-591.

Stephan, U. \&Uhlaner, L. (2010). Performance-based vs. socially-supportive culture: A cross-national study of descriptive norms and entrepreneurship. Journal of International Business Studies, 41, 1347-1364.

Taylor, M. Z. \& Wilson, S. (2012). Does culture still matter? The effects of individualism on national innovation rates. Journal of Business Venturing, 27(2), 234-247.

Thomas, A, S.\& Mueller, S. L. (2000). A case for comparative entrepreneurship: Assessing the relevance of culture. Journal of International Business Studies, 31(2), 287-301.

Uhlaner, L. \&Thurik, A. R. (2007). Post materialism influencing total entrepreneurial activity across nations. Journal of Evolutionary Economics, 17(2), 161-185.

Van der Zwan, P.,Verheul, I., Thurik, A. R. \& Grilo, I. (2009). Entrepreneurial progress: Climbing the entrepreneurial ladder in Europe and the US. Tinbergen Institute Discussion paper TI2009-070/3, Erasmus School of Economics.

Vesalainen, J. \&Pihkala, T. (2000). Entrepreneurial Identity, Intentions and the Effect of the Push-Factor. International Journal of Entrepreneurship, 3(2), 145-151.

Wagner, J. \& Moch, M. (1986). Individualism-collectivism: concept and measure. Group Organ Stud, 11, 280304.

Wang, C. L., Siu, N. Y.\& Barnes, B. R. (2008). The significance of trust and rending in the long-term orientation of Chinese business-to-business relationships. Industrial Marketing Management, 37(7), 819-824.

Yau, O. H. M., Lee, J. S. Y., Chow, R. P. M., Sin, L. Y. M. \& Tse, A. C. B. (2000). Relationship marketing the Chinese way. Business Horizons, 43, 16-24. 